\title{
Prevalence and factors associated with physical inactivity among the elderly: a population-based study
}

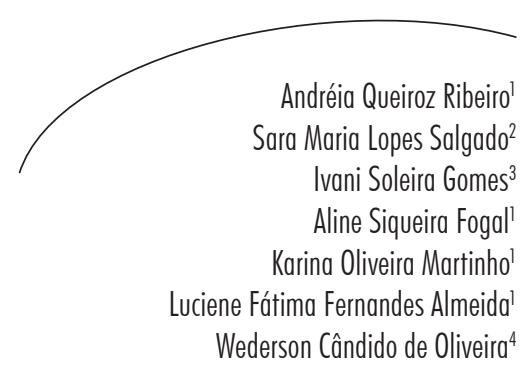

Abstract

Objectives: To determine the prevalence of physical inactivity among elderly individuals in the municipality of Viçosa, Minas Gerais and identify associated factors. Method: A crosssectional population-based study of 621 elderly persons was conducted in Viçosa, Minas Gerais. The dependent variable was physical inactivity, defined by the question "Do you practice some kind of physical activity?" The definition of the term "physical activity" was restricted to activities performed regularly, for at least 20 minutes, three times a week, disregarding domestic, industrial and transportation activities. The independent variables were age; gender; education; self-rated health; functional capacity; history of diabetes, hypertension, dyslipidemia and osteoporosis; overweight; risk of metabolic disorders; smoking; number of medical appointments; history of hospitalizations in the last year and private health insurance. Descriptive analysis and multiple Poisson regression were used. Results: The prevalence of physical inactivity was 70.1\% (95\% CI: 66.0\%$74.0 \%$ ). The associated factors were the male gender, aged over 80 years, less educated, low functional capacity, smokes and did not have private health insurance. Conclusion: The high prevalence of physical inactivity and its associated factors indicate the need to develop systematic approaches to improve public policies directed at this age group.

Key words: Physical Inactivity; Associated Factors; Elderly

\footnotetext{
Universidade Federal de Viçosa, Centro de Ciências Biológicas e da Saúde, Departamento de Nutrição e Saúde, Programa de Pós-graduação em Ciência da Nutrição. Viçosa, Minas Gerais, Brasil.

2 Universidade Federal de Viçosa, Centro de Ciências Biológicas e da Saúde, Departamento de Educação Física. Viçosa, Minas Gerais, Brasil.

3 Universidade Federal de Viçosa, Divisão de Extensão, Núcleo de Apoio a Programas e Projetos de Extensão. Viçosa, Minas Gerais, Brasil.

4 Universidade Federal de Viçosa, Centro de Ciências Biológicas e da Saúde, Departamento de Nutrição e Saúde. Viçosa, Minas Gerais, Brasil.
} 


\section{INTRODUCTION}

Studies have identified a heightened prevalence of physical inactivity among elderly Brazilians..$^{1-3}$ In the opinion of the World Health Organization, this tendency represents a major public health problem and a major modifiable risk factor for the development of chronic noncommunicable diseases (CNCD). ${ }^{4,5}$

Physical inactivity is considered the fourth greatest risk factor for mortality, contributing to the death of approximately 3.2 million people every year. People who do not exercise have a $20 \%$ to $30 \%$ greater risk of mortality from any cause than individuals who perform at least 30 minutes of physical activity on most days of the week. ${ }^{4}$

There are numerous factors that can contribute to physical inactivity among the elderly. Low socioeconomic status; functional impairment; presence of disease; fear of injury; lack of company; an unsuitable local environment or climate and a lack of infrastructure are some of the barriers to physical activity identified by the elderly. ${ }^{6-8}$

In Brazil, $72 \%$ of causes of deaths are attributed to $\mathrm{CNCD}$ s. In such a climate, a strategic action plan for dealing with chronic noncommunicable diseases (CNCDs) in Brazil 2011-2022 was created. One of the objectives of this plan is the development and implementation of effective public policies for the control of risk factors for CNCDs, which include physical inactivity. ${ }^{5}$

It is therefore important that each municipal region identifies factors associated with the physical inactivity of the elderly, in order to enable the development of local public health policies that encourage physical activity among people in this age group. This study sought to determine the prevalence of physical inactivity among the elderly in Viçosa (Minas Gerais) and identify associated factors.
METHOD

A cross-sectional population-based random sample study was conducted from June to December 2009 in Viçosa, in the state of Minas Gerais in Brazil, of individuals aged 60 or older resident in rural and urban areas. The municipality is located in a mining and forestry region, and in 2007 , had a population of 70,404 inhabitants, of whom 7,034 were elderly.

For the establishment of the cadastral base of individuals, the census carried out during the National Vaccination Campaign for the Elderly between April and May 2008 was used. In order to identify non-participants in the vaccination campaign and complement the cadastral base, this database was amalgamated with other available databases, namely: the database of the Servidores da Universidade Federal de Viçosa (e of the Federal University of Viçosa) (active and retired); the records of elderly persons registered with the Estratégia de Saúde da Família (the Family Health Strategy) (ESF), the databases of the municipal physiotherapy service, the women's health center, the psycho-social service, and the HiperDia (Hypertensives and Diabetics) and Polyclinic services. After the amalgamation of the databases, the records of people aged 60 and over totaled 7,980 people, a number that served as the basis for obtaining the sample. Institutionalized elderly persons were excluded.

The sample size calculation considered a confidence level of $95 \%$, an estimated prevalence of $50 \%$ and a tolerated error of $4 \%$. Thus, the sample comprised 558 elderly persons, to which $20 \%$ was added to cover possible losses, giving a total of 670 elderly persons to be studied. There were losses of information due to refusal $(3.6 \%)$ and for unavoidable reasons for not participating in interviews (3.7\%). The following losses were considered unavoidable: randomly selected individuals who had already died (1.3\%), addresses 
which were not found $(1.2 \%)$ and elderly individuals who had moved to difficult to access locations and other municipal regions (1.2\%). Thus, 621 elderly people were effectively studied.

The interviews were home-based and preferably pre-scheduled. The information was obtained through a semi-structured questionnaire with mostly closed and pre-coded questions. The questionnaire was applied directly to the elderly individuals and if they had difficulty answering, their closest companion provided assistance.

For anthropometric assessment, weight was measured with a portable scale (digital and electronic), with a capacity of $199.95 \mathrm{~kg}$ and a precision of 50 grams. The elderly used light clothing, did not wear shoes or sweaters, and stood in an orthostatic position with arms outstretched and eyes on the horizon. ${ }^{9}$ Height was measured with the aid of a portable stadiometer with a length of 2.13 meters, divided into centimeters and subdivided into millimeters. To measure height, the elderly individuals stood without shoes and with their heels together in an upright position, with their backs to the stadiometer, and stared straight ahead at the height of the horizon. ${ }^{9}$

The weight and height measurements of elderly persons with postural problems, amputated legs or who had difficulty standing up were excluded. This corresponded to $11.3 \%(n=70)$ and $2.6 \%$ $(n=16)$ of the sample, respectively, although other information relating to these individuals was retained for analysis.

Waist circumference was measured by positioning a non-extending and inelastic tape at the midpoint between the lower margin of the last rib and the most protruding point of the iliac crest, on the horizontal plane. ${ }^{10}$

The dependent variable analyzed was physical inactivity, defined by the following question: "Do you do any physical activity?" Physical activity was defined as that which is undertaken regularly for at least 20 minutes, three times a week, disregarding other dimensions of activities carried out at home, at work, or when travelling.

The independent variables analyzed were:

Sociodemographic characteristics: age (60-69 years, 70-79 years and 80 years or more); gender (male, female), education (never studied, studied up to early grades of elementary school, and up to the final grades of elementary school or more). Indicadores of health and nutrition: perception of own health (very good/good, regular, or poor/ very poor); functional capacity (normal and low); morbidity (history of diabetes, hypertension, dyslipidemia and osteoporosis); overweight (yes/ no) and risk of metabolic disorder (yes/no). Life habits: smoking (no history of smoking, former smoker, current smoker). Indicators of use of health service: number of medical appointments in previous year (one to five times, six times or more); history of hospitalization in 12 months prior to interview (none, one or more) and possessed private health plan (yes/no).

A self-assessment scale with 12 types of activities was used to evaluate functional capacity. These included activities of daily living (ADLs) and instrumental activities of daily living (IADL). For the ADL group, the Katz scale ${ }^{11}$ was used, which includes: bathing, dressing, eating, toileting, walking from room to room in the house and getting up from the bed to a chair. The following activities were considered for the IADL: preparing food or cooking; using the phone; leaving the house or taking a bus; taking medication; managing money; shopping; cleaning the house; doing household crafts and washing and ironing clothes. ${ }^{12}$ The assessment of the ability to perform the ADL and IADL was divided into the following categories: 1. has no difficulty; 2 . has little difficulty; 3 . has great difficulty; 4. cannot perform and 5. does not perform. For statistical analysis functional capacity was dichotomized into normal and low, according to the methodology proposed by Fielder $\&$ Peres. ${ }^{13}$ In this way, individuals who reported 
some difficulty in performing six or more activities (categories 2 and 3) or who evaluated themselves as being unable to perform at least three activities of the total of 12 considered (category 4) were considered as having low functional capacity.

Morbidities were investigated by asking whether "a doctor or other health professional has ever diagnosed any particular condition," such as hypertension, diabetes, hyperlipidemia or osteoporosis.

Overweight was classified by body mass index (BMI), which was used to characterize the nutritional status of the elderly into: underweight $<22 \mathrm{~kg} / \mathrm{m}^{2}$, eutrophic between 22 and $27 \mathrm{~kg} / \mathrm{m}^{2}$ and overweight $>27 \mathrm{~kg} / \mathrm{m}^{2}$, in accordance with Lipschitz. ${ }^{14}$

The risk of metabolic change was classified by cutoff points for waist circumference, with an increased risk for women at $\geq 80 \mathrm{~cm}$ and for men at, $\geq 94 \mathrm{~cm}^{15}$

Descriptive analysis consisted of frequency distributions for the qualitative variables and the obtaining of estimates of central tendency and dispersion for quantitative variables. The prevalence of physical inactivity was estimated, and a respective confidence interval of $95 \%$ was considered.

The differences between proportions were tested using the Pearson Chi-squared test and Chi-squared linear trend test. Poisson regression with robust variance was used to obtain prevalence ratio estimates and their respective $95 \%$ confidence intervals for the association between physical inactivity and the variables of interest in the study. Variables associated with the dependent variable with a significance less than 0.20 in bivariate analysis were included in the multiple Poisson model. The variables associated with the dependent variable with a significance level less than 0.05 remained in the final model.

The Stata version 13.0 (Stata Corp., College Station, USA) software package was used for data analysis. A statistical significance level of ()$=0.05$ was adopted for all comparisons for the rejection of the null hypothesis.

The study complied fully with the guidelines for research involving humans of Resolution $n^{\circ}$ 196/96 of the Conselho Nacional de Saúde (National Health Council). The research project was approved by the Ethics Research Committee of the Universidade Federal de Viçosa (Viçosa Federal University) ( $\mathrm{n}^{\circ} 027 / 2008$ ) and all the volunteers involved signed a Free and Informed Consent Form.

\section{RESULTS}

Of the 621 elderly persons interviewed, 53.3\% $(n=331)$ were female. The average age of the elderly persons was $70.8( \pm 8.1)$ years, varying from 60 to 98 years. Around half the elderly persons were aged between 60 and 69 years (50.1\%) and 15.0\% had 80 years or more. More than half reported having studied until the early grades of elementary school $(64.0 \%)$ and $15.0 \%$ said they had never studied.

The prevalence of physical inactivity was 70.1\% (95\% CI: 66.0\%-74.0\%). All the selected sociodemographic variables were significantly associated with physical inactivity, with higher prevalence among men, older elderly persons and those with no education (Table 1). 
Table 1. Prevalence and prevalence ratio of physical inactivity based on sociodemographic variables of the elderly. Viçosa-MG, 2009.

\begin{tabular}{|c|c|c|c|c|}
\hline Variables & $\begin{array}{l}\text { Total } \\
\text { n }(\%)\end{array}$ & Prevalence $(\%)$ & $\begin{array}{c}\text { PR } \\
(\mathrm{CI} 95 \%)\end{array}$ & Value $p$ \\
\hline Gender & & & & $0.023 *$ \\
\hline Female & 331 (53.3) & 66.2 & 1.0 & \\
\hline Male & $290(46.7)$ & 74.5 & $1.12(1.02-1.25)$ & \\
\hline Age range (years) & & & & $0.001^{\#}$ \\
\hline 60 to 69 & $311(50.1)$ & 65.3 & 1.00 & \\
\hline 70 to 79 & $216(34.8)$ & 71.3 & $1.09(0.97-1.22)$ & \\
\hline 80 and above & $94(15.1)$ & 82.9 & $1.27(1.12-1.44)$ & \\
\hline Education & & & & $0.000^{\#}$ \\
\hline $\begin{array}{l}\text { Later grades of elementary } \\
\text { school or higher }\end{array}$ & $129(20.8)$ & 51.2 & 1.00 & \\
\hline $\begin{array}{l}\text { Up to early grades of } \\
\text { elementary school }\end{array}$ & $397(64.0)$ & 73.6 & $1.44(1.20-1.72)$ & \\
\hline Never studied & $94(15.2)$ & 80.8 & $1.58(1.30-1.92)$ & \\
\hline
\end{tabular}

*Pearson Chi-squared; ${ }^{*}$ Linear tendency Chi-squared.

As shown in Table 2 , a more negative perception of health, the presence of cognitive impairment, low functional capacity and smoking were positively and statistically significantly associated with physical inactivity. On the other hand, there was a lower prevalence of physical inactivity among older adults with a history of dyslipidemia and increased risk of metabolic changes in comparison to their peers, and this association was statistically significant. 
Table 2. Prevalence and Prevalence ratio of physical inactivity based on variables of health condition, nutrition and lifestyle of elderly persons. Viçosa-MG, 2009.

\begin{tabular}{|c|c|c|c|c|}
\hline Variables & $\begin{array}{l}\text { Total } \\
\text { n (\%) }\end{array}$ & $\begin{array}{c}\text { Prevalence } \\
(\%)\end{array}$ & $\begin{array}{c}\text { PR } \\
\text { (CI 95\%) }\end{array}$ & Value $p$ \\
\hline Perception of health & & & & $0.001^{\#}$ \\
\hline Good or very good & $272(45.4)$ & 62.9 & 1.0 & \\
\hline Regular & $289(48.3)$ & 72.3 & $1.15(1.02-1.29)$ & \\
\hline Poor or very poor & $38(6.3)$ & 86.8 & 1.38 (1.18-1.61) & \\
\hline Functional capacity & & & & $0.000^{*}$ \\
\hline Normal & $519(83.8)$ & 66.5 & 1.0 & \\
\hline Low & $100(16.2)$ & 89.0 & $1.34(1.22-1.47)$ & \\
\hline History of Diabetes & & & & $0.61)^{*}$ \\
\hline No & $482(77.6)$ & 70.5 & 1.0 & \\
\hline Yes & $139(22.4)$ & 68.4 & $0.97(0.85-1.10)$ & \\
\hline History of Hypertension & & & & $0.639 *$ \\
\hline No & $146(23.5)$ & 68.5 & 1.0 & \\
\hline Yes & $475(76.5)$ & 70.5 & $1.03(0.91-1.17)$ & \\
\hline History of dyslipidemia & & & & $0.001^{*}$ \\
\hline No & $267(43.1)$ & 77.2 & 1.0 & \\
\hline Yes & $353(56.9)$ & 64.6 & $0.84(0.76-0.93)$ & \\
\hline History of Osteoporosis & & & & $0.579 *$ \\
\hline No & $526(84.8)$ & 69.6 & 1.0 & \\
\hline Yes & $94(15.2)$ & 72.3 & $1.04(0.91-1.19)$ & \\
\hline Smoker & & & & $0.000 *$ \\
\hline Never smoked & $345(55.7)$ & 67.8 & 1.0 & \\
\hline Ex-smoker & $207(33.5)$ & 66.7 & $0.98(0.87-1.11)$ & \\
\hline Smoker & $67(10.8)$ & 91.0 & $1.34(1.21-1.49)$ & \\
\hline Overweight & & & & $0.541 *$ \\
\hline No & $303(55.0)$ & 69.0 & 1.0 & \\
\hline Yes & $248(45.0)$ & 66.5 & $0.99(0.87-1.12)$ & \\
\hline Risk of metabolic disorder ${ }^{\# \#}$ & & & & $0.034 *$ \\
\hline Low & 147 (24.6) & 66.9 & 1.0 & \\
\hline High & $450(75.4)$ & 76.1 & $0.88(0.78-0.98)$ & \\
\hline
\end{tabular}

*Pearson Chi-Squared; ${ }^{2}$ Linear Tendency Chi-squared; \#\# risk of metabolic disorder: circumference of waist $<80 \mathrm{~cm}$ for women and $<94 \mathrm{~cm}$ for men, heightened risk of metabolic disorder: circumference of waist $\geq 80 \mathrm{~cm}$ for women and $\geq 94 \mathrm{~cm}$ for men. 
Regarding the variable use of health services, only the variable possessing a private health plan was significantly associated with physical inactivity. In this case, it was observed that physical inactivity among older adults without health plans was 1.28 times more prevalent than those who reported having health insurance (Table 3).

Table 3. Prevalence and prevalence ratio of physical inactivity based on variables of use of health services by the elderly. Viçosa-MG, 2009.

\begin{tabular}{lcccc}
\hline \multicolumn{1}{c}{ Variables } & $\begin{array}{c}\text { Total } \\
\mathrm{n}(\%)\end{array}$ & Prevalence $(\%)$ & $\begin{array}{c}\text { PR } \\
(\text { CI 95\%) }\end{array}$ & Value $p$ \\
\hline $\begin{array}{l}\text { Number of medical appointments } \\
\text { in previous year }\end{array}$ & & & & $0.977^{\#}$ \\
$\quad$ Six times or more & $126(20.3)$ & 76.19 & 1.0 & \\
$\quad$ One to five times & $449(72.4)$ & 66.81 & $0.88(0.78-0.99)$ & \\
$\quad$ None & $45(7.3)$ & 86.66 & $1.14(0.98-1.32)$ & \\
History of hospitalization & & & & $0.085^{*}$ \\
$\quad$ No & $526(84.8)$ & 68.8 & 1.0 & \\
$\quad$ Yes & $94(15.2)$ & 77.7 & $1.13(0.99-1.28)$ & \\
Private health plan & & & & $\mathbf{0 . 0 0 0 *}$ \\
Yes & $334(53.9)$ & 62.0 & 1.0 & \\
No & $286(46.1)$ & 79.7 & $1.28(1.16-1.42)$ & \\
\hline
\end{tabular}

*Pearson Chi-Squared; "Linear Tendency Chi-squared.

Multiple regression analysis revealed that the independent factors positively associated with physical inactivity among the elderly studied were: male gender, older age, lack of education, low functional capacity, smoking and non-affiliation to a private health plan. In contrast, a history of dyslipidemia remained negatively associated with physical inactivity (Table 4). 
Table 4. Final results of multivariable analysis of factors associated with physical activity among the elderly. Viçosa-MG, 2009.

\begin{tabular}{|c|c|c|}
\hline Variables & PR (CI 95\%) & Value $p$ \\
\hline Gender & & 0.014 \\
\hline Female & 1.0 & - \\
\hline Male & $1.15(1.03-1.29)$ & \\
\hline Age range (years) & & 0.015 \\
\hline 60 to 69 & 1.00 & \\
\hline 70 to 79 & $1.05(0.94-1.18)$ & \\
\hline 80 and above & $1.16(1.03-1.32)$ & \\
\hline Education & & 0.000 \\
\hline $\begin{array}{l}\text { Later grades of elementary } \\
\text { school or higher }\end{array}$ & 1.00 & \\
\hline Up to early grades of elementary school & $1.28(1.07-1.54)$ & \\
\hline Never studied & $1.30(1.05-1.60)$ & \\
\hline Functional capacity & & 0.000 \\
\hline Normal & 1.0 & \\
\hline Low & $1.27(1.15-1.41)$ & \\
\hline History of dyslipidemia & & 0.053 \\
\hline No & 1.0 & \\
\hline Yes & $0.91(0.82-1.00)$ & \\
\hline \multicolumn{3}{|l|}{ Smoking } \\
\hline Never smoked & 1.0 & 0.000 \\
\hline Ex-smoker & $0.96(0.85-1.09)$ & \\
\hline Smoker & $1.26(1.11-1.43)$ & \\
\hline Private health plan & & 0.008 \\
\hline Yes & 1.0 & \\
\hline No & $1.15(1.04-1.28)$ & \\
\hline
\end{tabular}

\section{DISCUSSION}

The final multivariate analysis results indicated that elderly men aged 80 and older who were less educated, had low functional capacity, and were smokers without a private health plan had a higher prevalence of physical inactivity.

Although the high percentage of physical inactivity $(70.1 \%$; CI 95\%: $66.0 \%-74.0 \%)$ was similar to other studies of elderly Brazilians, ${ }^{1,3,16}$ it was lower than studies of the elderly in the south and northeast of the country. ${ }^{2,17}$

The higher prevalence of physical inactivity among elderly men contradicted the findings of studies by Alves et al. ${ }^{1}$ and Queiroz et al., ${ }^{2}$ which found no difference in the prevalence of physical inactivity between the genders. This result can be attributed to the presence of a culturally constructed model of masculinity, in which men are considered to be strong and tough, 
thus hampering the adoption of healthy habits such as preventive behavior. ${ }^{18} \mathrm{~A}$ study by Brito \& Camargo $^{19}$ also reflects on the issue of different beliefs regarding how men and women care for their health. According to this study, the social representation of the health and disease process for men is connected with its curative aspect, while for women the same process is more linked with its preventive aspect. This finding also helps explain the higher prevalence of physical inactivity among elderly men in this sample.

The higher prevalence of physical inactivity among older elderly people can be explained by the presence of barriers such as physical limitations, fear of falls, the presence of pain, lack of energy, lack of confidence and a fear of failing to perform the exercise due to never having previously attempted it. ${ }^{8,20}$

In this study, the educational history of the group analyzed was marked by a low educational level, with the majority (79.2\%) reporting a maximum level of schooling of having concluded the early grades of elementary school, or never having studied, a similar result to previous findings related to Brazilian elderly persons. ${ }^{21}$ Studies have shown that lower levels of education are associated with less physical activity. ${ }^{22,23}$ This scenario may contribute to worsening health conditions among individuals of lower socioeconomic status, which is evident in studies on inequalities in health. ${ }^{24}$

The association between functional incapacity and physical inactivity was positive and statistically significant, showing the importance of performing physical activities in order to maintain functional capacity. According to Virtuoso Júnior et al., ${ }^{25}$ 280 minutes/week of physical activity for women and 410 minutes/week of physical activity of men can predict an absence of functional incapacity. Regular physical activity is essential for maintaining strength, flexibility, muscular endurance, agility and balance, essential for maintaining the functional capacity of the elderly. ${ }^{26}$

In Latin America, one in four elderly people have difficulty in carrying out their daily activities. ${ }^{27}$ In Brazil, $25 \%$ of elderly persons reported having limitations or difficulties when performing their habitual activities because of a health problem or incapacity. ${ }^{28}$ Thus, sedentary lifestyles and an increase in CNCD often create a vicious circle: disease and disability reduce the level of physical activity which, in turn, predisposes the elderly to an increased risk of disease and disability. ${ }^{29}$

Among elderly smokers the prevalence of physical inactivity was 1.26 times greater than it was for non-smokers. Smoking is widely described as more prevalent in sedentary individuals while physical exercise is considered a protective factor against beginning smoking. ${ }^{30}$ Smoking contributes doubly to the impairment of health, as in this study, inactivity positively associated with smoking, which has been identified as a risk factor for a number of diseases.-

Elderly holders of health plans declared that they participated more in physical activity than those who did not. Possessing a health plan is related to higher socioeconomic status, a greater concern for health, and having greater access to information and services that determined healthy lifestyles.$^{31}$ However, studies correlating affiliation to health plans and the performance of physical activity are scarce.

The present study has a number of limitations. Firstly, the fragility of the variable "physical activity" should be noted, as the criteria used to assess the practice of such activity was not objective. Other studies, however, have used research tools of a similar nature, through the questions: "Do you perform regular physical activity or sports?", 32 "Have you performed physical activity in the last two weeks to improve your health, physical condition or for aesthetic or pleasurable purposes?"33 or, "How would you rate your physical activity for leisure purposes?". ${ }^{34}$ Another limitation refers to aspects of the dependent variable in this study. Surveys that only measure the level of leisure-based physical activities tend to underestimate this factor, as they do not consider activities such as commuting to work and domestic and occupational activities, which are more frequent in poorer individuals with lower levels of education. ${ }^{1}$ The cross-sectional design can also be characterized as a limitation, as 
it makes identifying the causality between physical inactivity and the other study variables impossible.

\section{CONCLUSION}

The final model of the results of the present study indicated a higher prevalence of physical inactivity among elderly men aged over 80 years who were less educated, had low functional capacity, smoked and did not have health insurance. Given these results, systematic strategies should be developed to improve public policies for this age group, with a view to improving their living habits. The identification and consideration of associated factors is of considerable relevance in the context of Public Health. Special attention should be directed at men, older elderly individuals, the less educated, those with impaired functional capacity, smokers and people with poor access to health care.

\section{REFERENCES}

1. Alves JGB, Siqueira FV, Figueiroa JN, Facchini LA, De Silveira DS, Piccini RX, et al. Prevalência de adultos e idosos insuficientemente ativos moradores em áreas de unidades básicas de saúde com e sem Programa Saúde da Família em Pernambuco, Brasil. Cad Saúde Pública 2010;26(3):543-56.

2. Queiroz BM, Coqueiro RS, Leal Neto JS, Borgatto AF, Barbosa AR, Fernandes MH. Inatividade física em idosos não institucionalizados: estudo de base populacional. Ciênc Saúde Coletiva 2014;19(8):3489-96.

3. Freire RS, Lélis FLO, Fonseca Filho JA, Nepomuceno MO, Silveira MF. Prática regular de atividade física: estudo de base populacional no norte de Minas Gerais, Brasil. Rev Bras Med Esporte 2014;20(5):345-9.

4. World Health Organization. Global status report on noncommunicable diseases 2010. Geneva: WHO; 2011.

5. Brasil. Ministério da Saúde, Secretaria de Vigilância em Saúde, Departamento de Análise de Situação de Saúde. Plano de ações estratégicas para o enfrentamento das doenças crônicas não transmissíveis (DCNT) no Brasil 2011-2022. Brasília: Ministério da Saúde; 2011. (Série B. Textos Básicos de Saúde).

6. Maciel MG. Atividade física e funcionalidade do idoso. Motriz 2010;16(4):1024-32.

7. Giehl MWC, Schneider IJC, Corseuil HX, Benedetti TRB, D'Orsi E. Atividade física e percepção do ambiente em idosos: estudo populacional em Florianópolis. Rev Saúde Pública 2012;46(3):516-25.

8. Krug RR, Lopes MA, Mazo GZ, Marchesan M. A dor dificulta a prática de atividade física regular na percepção de idosas longevas. Rev Dor 2013;14(3):192-5.

9. World Health Organization. Physical status: the use and interpretation of anthropometry. Adults 60 years of age and older. Geneva: WHO; 1995. p. 375-411.

10. Cameron N. The measurement of human growth. London: Croom-Helm; 1984.

11. Katz S, Ford A, Moskowitz R, Jackson B, Jaffe M. Studies of illness in the aged. The index of ADL, a standardized measure of biological and psychosocial function. JAMA 1963;185(12):914-9.

12. Lawton M, Brody E. Assessment of older people: self maintaining and instrumental activies of daily living. Gerontologist 1969;9(3 Part 1):179-86.

13. Fiedler MM, Peres KG. Capacidade funcional e fatores associados em idosos do sul do Brasil: um estudo de base populacional. Cad Saúde Pública 2008;24(2):409-15.

14. Lipschitz D. Screening for nutricional status in the elderly. Prim Care 1994;21(1):55-67.

15. World Health Organization. Obesity: preventing and managing the global epidemic. Report of a WHO Consulation on Obesity. WHO: Geneva; 1998. (Technical Report Series 894, Part 1).

16. Rocha SV, Almeida MMG, Araújo TM, Santos LB, Rodrigues WKM. Fatores associados à atividade física insuficiente no lazer entre idosos. Rev Bras Med Esporte 2013;19(3):191-5.

17. Benedetti TRB, Mazo GZ, Borges LJ. Condições de saúde e nível de atividade física em idosos participantes e não participantes e grupos de convivência de Florianópolis. Ciênc Saúde Coletiva 2012;17(8):2087-93. 
18. Gomes R, Nascimento EF. A produção do conhecimento da saúde pública sobre a relação homem-saúde: uma revisão bibliográfica. Cad Saúde Pública 2006;22(5):901-11.

19. Brito AMM, Camargo BV. Representações sociais, crenças e comportamentos de saúde: um estudo comparativo entre homens e mulheres. Temas Psicol 2011;19(1):283-303.

20. Krug RR, Lopes MA, Mazo GZ. Barreiras e facilitadores para a prática da atividade física de longevas inativas fisicamente. Rev Bras Med Esporte 2015;21(1):57-64.

21. Instituto Brasileiro de Geografia e Estatística. Síntese de Indicadores Sociais: uma análise das condições de vida da população brasileira. Rio de Janeiro: IBGE; 2009. (Estudos e Pesquisas. Informação Demográfica e Socioeconômica, no 26).

22. Martins TG, Assis MAA, Nahas MV, Gauche $\mathrm{H}$, Moura EC. Inatividade física no lazer de adultos e fatores associados. Rev Saúde Pública 2009;43(5):814-24.

23. Costa EF. Prática de atividade física e sua relação com a escolaridade em adultos de Ermelino Matarazzo, Zona Leste de São Paulo, SP [dissertação]. São Paulo: Faculdade de Saúde Pública; 2009.

24. Barros MBA, César CLG, Carandina L, Torre GD. Desigualdades sociais na prevalência de doenças crônicas no Brasil, PNAD-2003. Ciênc Saúde Coletiva 2006;11(4):911-26.

25. Virtuoso Júnior JS, Tribess S, De Paulo TRS, Martins CA, Romo-Perez V. Atividade física como indicador preditivo para a incapacidade funcional em pessoas idosas. Rev Latinoam. Enferm 2012;20(2):259-65.

26. Carmo NM, Mendes EL, Brito CJ. Influência da atividade física nas atividades da vida diária de idosas. Rev Bras Ciênc Envelhec Hum 2008;5(2):16-23.
27. Organização Pan-americana da Saúde. Anais da 26a Conferência Sanitária Pan-americana; 26 - 27 de setembro de 2002. Washington: Organização Panamericana de Saúde, Organização Mundial de Saúde; 2002.

28. Nunes D, Nakatani A, Silveira E, Bachion M, Souza M. Capacidade funcional, condições socioeconômicas e de saúde de idosos atendidos por equipes de Saúde da Família de Goiânia (GO, Brasil). Ciênc Saúde Coletiva 2010;15(6):2887-98.

29. Coelho C, Burini R. Atividade física para prevenção e tratamento das doenças crônicas não transmissíveis e da incapacidade funcional. Rev Nutr 2009;22(6):937-46.

30. Patterson F, Lerman C, Kaufmann VG, Neuner GA, Audrian-McGovern J. Cigarette smoking practices among american college students: review and future directions. J Am Coll Health 2004;52(5):203-10.

31. Cassou ACN, Fermino RC, Santos MS, RodriguesAñez CR. Barreiras para a atividade física em idosos: uma análise por grupos focais. Rev Educ Fís 2008;19(3):353-60.

32. Gomes VB, Siqueira KS, Sichieri R. Atividade física em uma amostra probabilística da população do município do Rio de Janeiro. Cad Saúde Pública 2001;17(4):969-76.

33. Alves R, Mota J, Costa M, Alves J. Aptidão física relacionada à saúde de idosos: influência da hidroginástica. Rev Bras Med Esporte 2004;10(1):31-7.

34. Siqueira FV, Facchini LA, Piccini RX, Tomasi E, Thumé E, Silveira DS, et al. Atividade física em adultos e idosos residentes em áreas de abrangência de unidades básicas de saúde de município das regiões Sul e Nordeste do Brasil. Cad Saúde Pública 2008;24(1):39-54. 